\title{
PROBIOTIC EFFECT OF LACTOBACILLI ON MICE INCISIONAL WOUND INFECTIONS
}

\author{
Harith Jabbar Fahad Al-Mathkhury and Hind Jabbar Abdul-Rahman Al-Aubeidi \\ University of Baghdad, College of Science, Department of Biology.
}

\begin{abstract}
Three lactobacilli species, namely; L. bulgaricus, L. plantarum, and L. acidophilus were isolated from yoghurt, vinegar, and vagina, respectively, showed inhibition activity on Pseudomonas aeruginosa and Staphylococcus aureus isolated from several wound infections specimens. However, $S$. aureus was more affected than $P$. aeruginosa by the all lactobacilli isolates, on the other hand, L. plantarum showed the highest inhibition activity on both pathogenic isolates. Lactobacillus plantarum cells or supernatant succeeded in preventing $S$. aureus and $P$. aeruginosa from establishing wound infection. Since the inflammation and histopathological signs which developed by either $S$. aureus or $P$. aeruginosa were disappeared when the wounds were treated by lactobacilli cells or supernatant.
\end{abstract}

\section{Introduction}

Lactobacilli are non-pathogenic, grampositive lactic acid bacteria found in the normal intestinal microflora of animals and humans (1) and are classified as probiotic agents. Lactobacillus derived products, including culture supernatants have been used for their wound healing and antiviral properties as they are believed to boost energy and to be effective remedies for allergies, common cold, lactose intolerance, and have also been shown to reduce cholesterol levels and the risk of colon cancer (2-4). Supernatants of Lactobacillus acidophilus were also proved to be effective against Helicobacter pylori in vitro and in vivo in people and were shown to possess antimicrobial activities against Bacillus anthracis and E. coli (3). Lactobacillus supernatants (LS) promote inflammatory response during tissue repair in rodents (5), stimulate proliferation of embryonic cells (6), and that subcutaneous injections of Lactobacillus supernatants into the ears of rats lead to angiogenesis (5). Using a cytokine antibody array, leptin and several other cytokines (e.g., IL-6, IL-8 and TGF $\beta$ ) were detected in medium conditioned by bovine endothelial cells exposed to LS

Fermented dairy products containing Lactobacillus have traditionally been used to modulate the microbial ecology (7) to prevent infection of pathogenic bacteria (8) to stimulate the immune system (9) and to

normalize gastrointestinal disorders (10). Also a significant probiotic strain with proven health benefits and therapeutic applications in the treatment of diarrhea (11) irritable bowel syndrome (12), atopic eczema (13) and the prevention of urinary tract infections (14).

Staphylococcus aureus is a major opportunistic pathogen that can cause a variety of local and systemic infections ranging from skin abscesses, bone and soft tissue surgical infections, sepsis, invasive endocarditis, and toxic shock syndrome (TSS) (15). Pseudomonas aeruginosa produces infection of wounds and burns, giving rise to blue-green pus; meningitis, and urinary tract infection, necrotizing pneumonia, otitis externa in swimmers. It may cause invasive (malignant) otitis externa in diabetic patients. Infection of the eye, occurs most commonly after injury or surgical procedures. In infants or debilitated persons, $P$ aeruginosa may invade the bloodstream and result in fatal sepsis; in patients with severe burns (15).

The aim of the present study was to determine, in a mouse animal model, the capability of Lactobacillus to inhibit the wound infection caused by pathogenic Staphylococcus aureus and Pseudomonas aeruginosa. 


\section{Materials and methods \\ Isolation and identification}

Pseudomonas aeruginosa and S.aureus were isolated from several wound infections specimens which obtained by sterile cotton swabs, streaked on blood agar, MacConkey agar plates and mannitol salt agar (all media were purchased from Himedia, India), incubated at $37^{\circ} \mathrm{C}$ for $24 \mathrm{~h}$., thereafter, the grown colonies were identified according to (16).

To isolate lactobacilli, three different samples: vinegar, yogurt, and vagina, were streaked onto De Mann-Rogosa-Sharpe (MRS) agar (Himedia, India) agar plates $(\mathrm{pH} 5.5)$ and incubated at $37^{\circ} \mathrm{C}$ for $48 \mathrm{~h}$ under anaerobic conditions. The Lactobacilli were initially identified by their ability to grow on the selective MRSA, gram-positive staining, rod shape, and catalase-negative phenotype. Biochemical analyses, including sugar fermentation profile and gas production in MRS broth, were conducted as described in (16).

Quantification of bacterial suspensions was adjusted to approximately $1.5 \times 10^{8} \mathrm{CFU} / \mathrm{ml}$ by comparison to McFarland turbidity standards confirmed by enumeration using the spread plate technique.

\section{In vitro study}

\section{Antibacterial activity of Lactobacillus cells coculture}

Lactobacilli were cultured anaerobically on MRS agar for $48 \mathrm{hrs}$. at $37^{\circ} \mathrm{C}$. Thereafter, 5 $\mathrm{mm}$ agar discs (triplicates) were cut out by a sterile Pasteur pipette and placed on a Muller Hinton agar (Himedia, India) plates seeded with $S$. aureus or $P$. aeruginosa. Then the plates were cultivated for $24 \mathrm{~h}$. at $37^{\circ} \mathrm{C}$. Inhibition zones were measured in millimeters by an ordinary ruler (17).

\section{Preparation of Lactobacillus supernatants}

Briefly, cultures of lactobacilli were grown in MRS broth (Himedia, India) at $37^{\circ} \mathrm{C}$ for 24 $\mathrm{hr}$ under anaerobic conditions. Overnight bacterial cultures contained $1.5 \times 10^{8} \mathrm{CFU} / \mathrm{ml}$, and these cultures were centrifuged at $10,000 \mathrm{~g}$ for $15 \mathrm{~min}$ at $4^{\circ} \mathrm{C}$. The resulting supernatants were filtered through a $0.2 \mu \mathrm{m}$ membrane filter to remove the remaining bacteria and debris
(18). Plating on MRS agar plates showed no evidence of lactobacilli growth.

\section{Antibacterial activity of Lactobacillus supernatants}

The bacterial suspension of $S$. aureus or $P$. aeruginosa was transferred evenly on three Mueller Hinton agar plates. Four wells were made in each agar plate with a sterile Pasteur pipette; $50 \mu 1$ of culture supernatant from the three different lactic acid bacteria were added to three wells. While, in the fourth well MRS broth was added to determine possible inhibitory activity of the medium (as control). After aerobic incubation for $24 \mathrm{~h} 37{ }^{\circ} \mathrm{C}$ Inhibition zones were measured in millimeters by an ordinary ruler (19).

\section{In vivo study \\ Animals}

Six-week-old female white mice (Mus musculus) from the inbreed colony of department of biology, college of Science, university of Baghdad, each weighing from 25 to $30 \mathrm{~g}$, were used throughout the investigation. Animals were housed in plastic cages and fed ad libitum with a conventional diet. All the animals were randomly assigned to the following experimental groups (as triplicates): (1) sterile saline solution treated group, (2) Lactobacillus plantarum treated group, (3) L. plantarum supernatant treated group, (4) S. aureus treated group (5) $P$. aeruginosa treated group. (6) L. plantarum and S. aureus treated group, (7) L. plantarum supernatant and $S$. aureus treated group (8) $L$. plantarum with $P$. aeruginosa treated group, (9) L. plantarum supernatant with $P$. aeruginosa treated group.

\section{Microorganisms inoculation procedure}

Overnight cultures of lactobacilli grown in MRS broth, $P$. aeruginosa or $S$. aureus grown on brain hearth infusion broth (24 hours, $37^{\circ} \mathrm{C}$ ) were centrifuged at $10000 \mathrm{~g}$ for 10 minutes at $4^{\circ} \mathrm{C}$, washed twice with sterile saline solution.

Transcutaneous $6 \mathrm{~mm}$ in diameter wounds were performed on the backs of the mice as it described by (5), bacterial suspension or supernatant were applied to the wound using cotton swab. Mice were sacrificed after two days; the injured skin specimens were 
aseptically removed, fixed with $10 \%$ formalin for 24 hours at room temperature, and then embedded in paraffin according to standard histological methods (20).

\section{Statistical analysis}

The results were analysed statistically in the Statistical program with the rest of the Least Significant Difference (LSD).

\section{Results and discussion}

Three lactobacilli species L. bulgaricus, $L$. plantarum, and L. acidophilus were isolated from yoghurt, vinegar, and vagina, respectively.

Staphylococcus aureus and P. aeruginosa were inhibited, variably, by the supernatant as well as the coculture of the three isolates of Lactobacillus. However, L. plantarum showed the highest inhibition activity among the three lactobacilli Table (1). Depending on these results $L$. plantarum was elected for the in vivo study. However, these results strongly indicated that the source of lactobacilli is of great importance in the selection of probiotic microorganism.

Table (1)

Antibacterial activity of lactobacilli isolates.

\begin{tabular}{|c|c|c|c|c|}
\hline \multirow{3}{*}{ 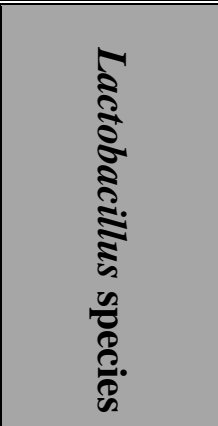 } & \multicolumn{4}{|c|}{ Zone of inhibition $(\mathrm{mm}) \pm$ SD } \\
\hline & \multicolumn{2}{|c|}{ P. aeruginosa } & \multicolumn{2}{|c|}{ S. aureus } \\
\hline & 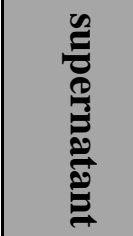 & 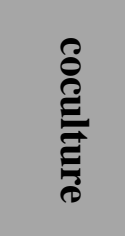 & 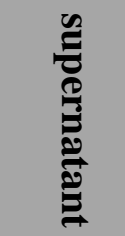 & 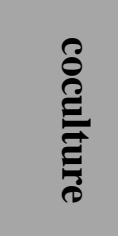 \\
\hline $\begin{array}{c}L . \\
\text { bulgaricus }\end{array}$ & $\begin{array}{c}13.5 \pm \\
1.5 \mathrm{a}\end{array}$ & $\begin{array}{c}13.3 \pm \\
2 \mathrm{a}\end{array}$ & $\begin{array}{l}17 \pm \\
1.7 \mathrm{~b}\end{array}$ & $\begin{array}{l}17.3 \pm \\
1.1 \mathrm{~b}\end{array}$ \\
\hline $\begin{array}{c}\text { L. } \\
\text { plantarum }\end{array}$ & $\begin{array}{c}20.3 \pm \\
0.5 \mathrm{c}\end{array}$ & $\begin{array}{c}19.3 \pm \\
0.5 c\end{array}$ & $\begin{array}{c}25.6 \pm \\
2.3 \mathrm{c}\end{array}$ & $\begin{array}{l}24.6 \pm \\
1.1 \mathrm{c}\end{array}$ \\
\hline $\begin{array}{c}L . \\
\text { acidophilus }\end{array}$ & $\begin{array}{l}8.6 \pm \\
0.5 \mathrm{~d}\end{array}$ & $\begin{array}{c}9 \pm \\
1.7 \mathrm{~d}\end{array}$ & $\begin{array}{c}12.6 \pm \\
2 \mathrm{a}\end{array}$ & $\begin{array}{r}14.3 \pm \\
1.5 \mathrm{a}\end{array}$ \\
\hline
\end{tabular}

Obviously, Table (1) demonstrates that $S$. aureus was more affected than $P$. aeruginosa by the all lactobacilli isolates, a result agreed with Gilliland and Speck (1977) (21) who reported that Lactobacilli showed stronger antibacterial properties against grampositive bacteria ( $S$. aureus and Clostridium perfringens) than gram-negative bacteria (Escherichia coli and Salmonella typhimurium). While others (22) reported that strains of Lactobacillus had an $85 \%$ inhibitory effect on $P$. aeruginosa and $48 \%$ S. aureus. Moreover, wild strains of Lactobacillus species were isolated from Kunun zaki (fermented millet drink) and Fresh Cow milk. The results showed that the isolates were found to be the most effective against $S$. aureus. Also observed to be next in effectiveness is against Escherichia coli. However, the least level of inhibition was recorded against Klebsiella pneumoniae. The inhibition recorded in the case of the isolates that have antagonistic effect may be due to the production of organic acids, bacteriocins and hydrogen peroxide (23).

Characterisation of the lactobacilli metabolic product for antimicrobial agents reveals that lactic acid may be responsible for the inhibition of the pathogenic bacteria (24).

In regard to the control group Fig. (1), $S$. aureus and $P$. aeruginosa were able to cause an infection in the experimentally wounds, represented by infiltration of inflammatory cells Fig.(2) and the dilatation along with increase in number of the blood capillaries, as it can be seen from Fig.(3). Such activity was observed in transcutaneous wounds in mice treated with Lactobacillus supernatant resulted in prolonged inflammatory phase of wound healing and delayed wound closure, including reepithelialization (5).

Lactobacillus plantarum cells or supernatant succeeded in preventing $S$. aureus and $P$. aeruginosa from establishing wound infection. Since the inflammation and histopathological signs which developed by either

S. aureus or $P$. aeruginosa were disappeared when the wounds were treated by lactobacilli cells

Each value is the mean of three replicate (mean $\pm S D)$ Values with different letter have significant differences (P>0.05) 


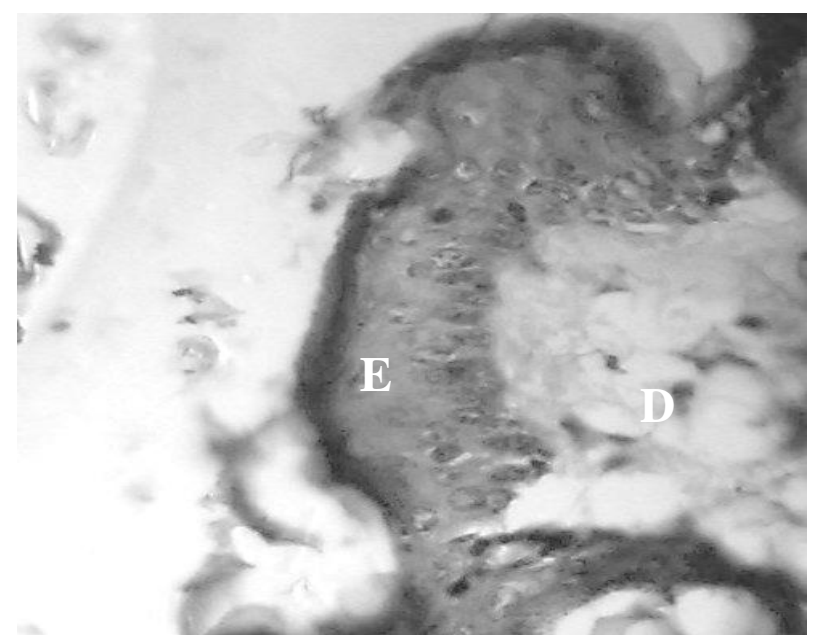

Fig.(1) : Normal mouse skin structure. $E=$ epidermis, $D=$ Dermis. $X 400, H \& E$.

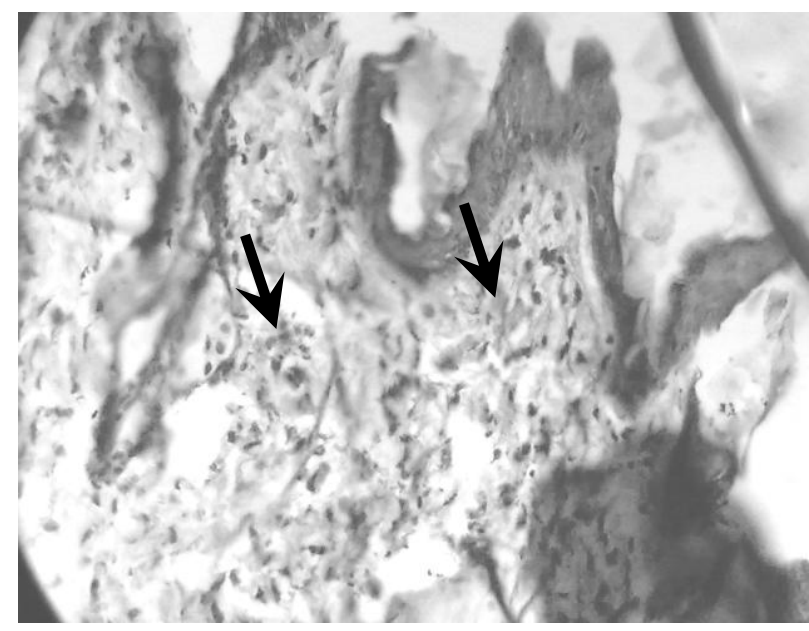

Fig.(2) : Mouse skin (wound) injected with $1.5 \times 10^{8} \mathrm{CFU} / \mathrm{ml}$ of $S$. aureus shows the infiltration of inflammatory cells (arrows). $X 400, H \& E$.

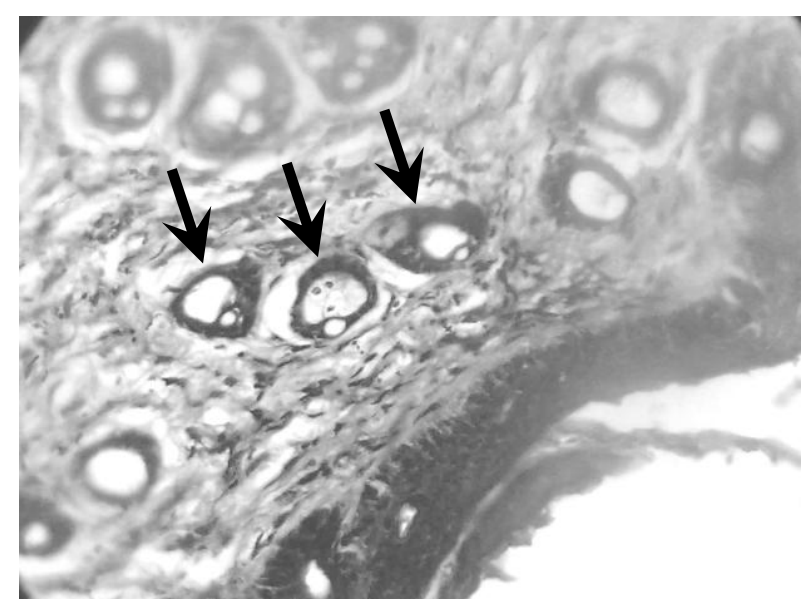

Fig.(3): Mouse skin (wound) injected with $1.5 \times 10^{8} \mathrm{CFU} / \mathrm{ml}$ of $S$. aureus shows numerous blood vessels (arrows) with open lumina. X400, H\&E. or supernatant. This result is confirmed with an another study revealed that L. plantarum, L. delbruekii, L. acidophilus, and L. brevis were shown to produce a bacteriocin-like substance. Their sensitivity varied greatly. L. plantarum produced a more heat stable bacteriocin than the other isolated strains, which exhibited a broad spectrum of inhibitory activity. The antibacterial activity of plantaricin was more potent than the other isolated strains (25).

Results of Valdez and others (26) indicated that L. plantarum and/or its by-products are potential therapeutic agents for the local treatment of $P$. aeruginosa burn infections due to the inhibition of $P$. aeruginosa colonization and there was an improvement in tissue repair, enhanced phagocytosis of $P$. aeruginosa by tissue phagocytes, and a decrease in apoptosis at 10 days.

\section{References}

[1] C. Bleau, L. Lamontagne, and R. Savard." New Lactobacillus acidophilus isolates reduce the release of leptin by murine adipocytes leading to lower interferon- $\gamma$ production". Clin Exper Immunol. Vol. 140, 2005, pp.427-435.

[2] M. Sanders, and T. Klaenhammer. "Invited review: the scientific basis of Lactobacillus acidophilus NCFM functionality as a probiotic", J Dairy Sci. Vol. 84, 2001, pp.319-331.

[3] P. Michetti, G. Dorta, P. Wiesel, D. Brassart, E. Verdu, M. Herranz, C. Felley, N. Porta, M. Rouvet, A. Blum, and I. Corthésy-Theulaz. "Effect of WheyBased Culture Supernatant of Lactobacillus acidophilus (johnsonii) La1 on Helicobacter pylori Infection in Humans". Digestion.Vol. 60, 1999, pp.203-209.

[4] I. Wollowski, S. Ji, A. Bakalinsky, C. Neudecker, and B. Pool-Zobel. 1999. Bacteria used for the production of yogurt inactivate carcinogens and prevent DNA damage in the colon of rats. J Nutr. Vol. 129, 1999, pp.77-82. 
[5] J. Halper, L. Leshin, S. Lewis, and W. Li. "Wound healing and angiogenic properties of supernatants from Lactobacillus cultures" Exp. Biol. Med. Vol. 228, 2003, pp.1329-1337.

[6] W. Li, B. Brackett, and J. Halper. "Culture supernatant of Lactobacillus acidophilus stimulates proliferation of embryonic cells”. Exp. Biol. Med. Vol. 230, 2005, pp. 494-501.

[7] C. Dunne. "Adaptation of bacteria to the intestinal niche: probiotics and gut disorder" Inflamm. Bowel. Dis. Vol. 7, 2001, pp. 136-145.

[8] S. Sarker, S. Sultana, G. Fuchs, N. Alam, T. Azim, H. Brussow, and L. Hammarstrom. "Lactobacillus paracasei strain ST11 has no effect on rotavirus but ameliorates the outcome of nonrotavirus diarrhea in children from Bangladesh". Pediatrics, Vol. 116, 2005, pp. e221-e228.

[9] N. Ibnou-Zekri, S. Blum, E. Schiffrin, W. von der "Divergent patterns of colonization and immune response elicited from two intestinal Lactobacillus strains that display similar properties in vitro". Infect. Immun. Vol. 71, 2003, pp. 428-436.

[10] F. Martin, M. Dumas, Y. Wang, C. Legido-Quigley, I. Yap, H. Tang, S. Zirah, G. Murphy, O. Cloarec, J. Lindon, N. Sprenger, L. Fay, S. Kochhar, B. van, E. Holmes, and J. Nicholson "A top-down systems biology view of microbiomemammalian metabolic interactions in a mouse model" Mol. Syst. Biol. Vol. 3, 2007, pp. 112.

[11] H. Szynanski, J. Pejcz, M. Jawien, A. Chmielarczyk, M. Strus, and P. Heczko, "Treatment of acute infectious characters in infants and children with a mixture of three Lactobacillus rhamnosus strains a randomized, double-blind, placebocontrolled trial" Aliment. Pharmacol. Ther., Vol. 23, 2006, pp. 247.

[12] K. Kajander, K. Hatakka, T. Poussa, M. Farkkila, R. Korpela "A probiotic mixture alleviates symptoms in irritable bowel syndrome patients: a controlled 6-month intervention". Aliment. Pharmacol. Ther., Vol. 22, 2005, pp. 387-394.
[13] B. Corcoran, C. Stanton, G. Fitzgerald, and R. Ross "Survival of probiotic lactobacilli in acidic environments is enhanced in the presence of metabolizable sugars". Appl. Environ. Microbiol. Vol. 71, 2005, pp. 3060-3067.

[14] G. Reid, and A. Bruce "Probiotics to prevent urinary tract infections: the rationale and evidence" World J. Urol. Vol. 24, 2006, pp. 28-32.

[15] G. Brooks, J. Butel, and S. Morse. "Medical microbiology $24^{\text {rd }}$ ed" MacGraw Hill co. New York. 2007.

[16] J. Holt, N. Kreig, P. Sneath, J. Staley, and S. Williams, "Bergey's manual of determinative bacteriology $9^{\text {th }}$ ed". Williams and Willikins Maryland, USA. 1994.

[17] A. Ligocka, and Z. Paluszak "Capability of lactic acid bacteria to inhibit pathogens in sewage sludge subjected to biotechnological processes". Bull. Vet. Inst. Pulawy. Vol. 49, 2005, pp, 23-27.

[18] R. Sousa, J. Halper, J. Zhang, S. Lewis, and W. Li "Effect of Lactobacillus acidophilus supernatants on body weight and leptin expression in rats BMC Complement" Altern. Med. Vol. 8. 2008, pp.5.

[19] S. Nikoskelainen, S. Salminen, G. Bylund, and A. Ouwehand. "Characterization of the Properties of Human- and Dairy-Derived Probiotics for Prevention of Infectious Diseases in Fish" Appl. Environ. Microbiol. Vol. 67, 2001, pp. 2430-2435.

[20] G. Humason, “Animal tissue technique $3^{\text {rd }}$ ed." W.H. Freeman Company, San Francisco, 1972. pp.641.

[21] S. Gilliland and M. Speck. "Antagonistic action of Lactobacillus acidophilus towards intestinal and food pathogen in associative culture". J. Food Protect. Vol. 40 1977, pp. 820-823.

[22] B. Aslim, and E. Kilic. "Some probiotic properties of vaginal lactobacilli isolated from healthy women". Jpn. J. infect. Dis. Vol. 59, 2006, pp. 249-253. 
[23] O. Olanrewaju, "Antagonistic Effect of Lactobacillus Isolates from Kunnu and Cowmilk on Selected Pathogenic Microorganisms". Internet J. Food Safety, Vol.9, 2007, p. 63-66

[24] V. Oyetayo. "Phenotypic characterization and assessment of the inhibitory potential of Lactobacillus isolates from different sources". Afr. J. Biotechnol. Vol. 3 , 2004, pp. 355-357.

[25] J. Nowroozi1, M. Mirzaii1, M. Norouzi. "Study of Lactobacillus as Probiotic Bacteria". Iranian J. Publ. Health, Vol.33, 2004. pp.1 -7.

[26] J. Valdez, M. Peral, M. Rachid, M. Santana, and G. Perdigon, "Interference of Lactobacillus plantarum with Pseudomonas aeruginosa in vitro and in infected burns: the potential use of probiotics in wound treatment". Clin. Microbiol. Infect. Vol.11, 2005, pp. 472-479.

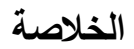

اظهرت ثلاثة انواع من بكتريا Lactobacillus وهي

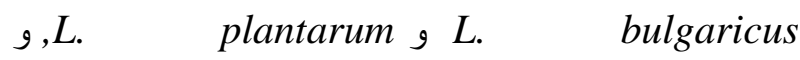

عزلت من اللبن و الخل و المهبل على L. plantarum

Pseudomonas

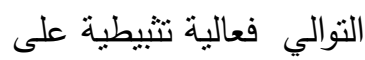

Staphylococcus aureus geruginosa

اخماج الجروح و تنين ان العزلة S. aureus كانت الاكثر

تاثرا من العزلة P. aeruginosa

Lactobacillus

L. اعلى فعالية تثنيطية في كلا العزلتين

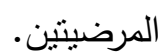

نجحت خلايا او طافي بكتريا L. plantarum في منع

كل من S. aeruginosa و. aureus من احداث خمج

جروح في الفئران فقد اختفى الالتهاب و العلامات المرضية من الدات

النسيجية التي تكونت بوساطة العزلة

P. aeruginosa

الجرح بخلايا او طافي بكتريا Lactobacillus. 